\title{
BIRDS OF A FEATHER: PREDATOR AND PREY IN CELESTINA
}

\author{
Laura Vivanco \\ University of St. Andrews
}

Two birds in particular, the partridge and Calisto's falcon, have attracted the attention of Celestina critics. ${ }^{1} \mathrm{~A}$ wider focus has been provided by Vicenta Blay Manzanera and Dorothy S. Severin, who have placed these birds in the context of animal imagery in the Celestina as a whole. It is my contention that there is still a need for a detailed study of the individual and collective significance of a particular group of birds: predators and their prey. I will therefore examine the interactions in Celestina between the neblí, gerifalte, milano, gallo, perdiz, gallina and pollo. The birds (both predators and prey) which glide through its pages are more than mere surface decoration; they illustrate one of the main themes of the work, the destructive nature of physical passion and the indiscriminate manner in which it affects all social classes. ${ }^{2}$

In the letter from 'el autor a un su amigo' Fernando de Rojas describes himself, at the moment of finding inspiration, as a creature of the air, "echando mis sentidos por ventores y mi juicio a volar" (6). ${ }^{3} \mathrm{He}$ draws a parallel between his faculties and the hunting dogs and trained birds of prey which co-operate in the hunt: he unleashes his dogs, his 'sentidos' and lets fly his bird of prey, his 'juicio'. ${ }^{4}$ Nevertheless, he modestly expresses the fear that his wings are weak and that the flight of fancy which leads him to venture into literary composition will cause his downfall: "a mí mismo mis alas destruyen, / Nublosas y flacas, nacidas de ogaño" (8). Bird imagery is further developed in the prose prologue in which Rojas restates Heraclitus's dictum, "Todas las cosas ser criadas a manera de contienda o batalla" (14), and develops the theme with particular reference to the avian world:

Pues si discurrimos por las aves y por sus menudas enemistades, bien afirmarémos ser todas las cosas criadas a manera de contienda. Las más viven de rapina, como halcones y águilas y gavilanes. Hasta los groseros milanos insultan dentro en nuestras moradas los 
domésticos pollos y debajo las alas de sus madres los vienen a cazar (16).

Thus, even before the work proper has commenced, bird imagery is used to suggest danger and conflict. Although Rojas's "alas" do not in fact destroy him, the participation of many of the characters of Celestina in the avian "hunt of love" does cause their downfall (both literal and metaphorical). We should therefore consider the wings acquired by the characters, either by association with real birds or through metaphor, as a potential danger to their owners. In addition to indicating danger, feathers may also reveal the truth. The literal feathering of Celestina by the law, which has had her "emplumada" (86) on a number of occasions, reveals her true nature. This punishment made a highly visible statement about the alcahueta's unlawful activities and was intended to make the public aware of her status. Sebastián de Covarrubias Horozco describes the procedure as follows:

A las alcahuetas acostumbran desnudarlas del medio cuerpo arriba $\mathrm{y}$, untadas con miel, las siembran de plumas menudas, que parecen monstruos, medio aves medio mugeres (Covarrubias Horozco 509). ${ }^{5}$

Rojas's feathered wings also reveal the truth since he wields his quill, "mi pluma" (8) in order to write a work which will make manifest the dangers of love and the foolishness of lovers: "Amantes, [...] os muestra salir de cativo" (8). Like the feathers applied by the justice system to the procuress, Rojas's "pluma" alerts the public, exposing "los engaños de las alcahuetas y malos y lisonjeros sirvientes" (20).

It is because the feathers reveal a verifiable truth about Celestina that Pármeno, warning Calisto against her, mentions the punishments she has received: "el amor parió tu pena; [...] y lo que más de ello siento es venir a manos de aquella trotaconventos, después de tres veces emplumada" (86). Pármeno begins this speech by reminding Calisto of the processes which have led him to fall in love: "porque perderse el otro día el neblí fue causa de tu entrada en la huerta de Melibea a le buscar; la entrada causa de la ver y hablar; la habla engendró amor" (86). Blay and Severin, commenting on this passage state that "The feathers of the bird of prey become the attire of the tarred and feathered procuress" (13). While I would agree that Rojas is playing with the imagery of feathering and plucking, I do not believe it is the nebli's feathers that are used to punish Celestina. As I hope to show below, Calisto's feathers would, if anything, be a reward for Celestina, not a punishment. When Sempronio mentions Celestina's feathering he is more playful than Pármeno, suggesting that to be plucked, "vengas sin pluma," would be almost as dangerous as to be "emplumada":

SEMP.-Madre, mira bien lo que haces, porque cuando el principio 
se yerra, no puede seguirse buen fin. Piensa en su padre, que es noble y esforzado, su madre celosa y brava, tú la misma sospecha. Melibea es única a ellos: faltándoles ella, fáltales todo el bien. En pensallo tiemblo; no vayas por lana y vengas sin pluma.

CEL.-¿Sin pluma, hijo?

SEMP.-O emplumada, madre, que es peor. (102).

On the metaphorical level, Celestina if caught would be plucked (destroyed) like the victim of a bird of prey. On the literal level, as an alcahueta, if she were discovered plying her trade she would be feathered. Celestina is also depicted as a predatory plucker of other birds' feathers, who is determined to "pluck" Calisto: as she says to Sempronio, were it not for the temporary impediment caused by Pármeno, "tu amo quedase sin pluma y nosotros sin queja" (98). ${ }^{6}$ When Celestina insinuates that she would like a new cloak, she is visualised by Pármeno as wishing to grow new feathers at Calisto's expense: "Pelechar quiere la vieja" (150). Gaining feathers can therefore be dangerous, as it is for Celestina when she is feathered, or advantageous, as when she seeks to gain benefits from Calisto. This playing with the image of feathers continues the theme of life as conflict, which Rojas provided in his prose prologue. It also alerts us to the fact that the role of the defeathered and the defeatherer (or plucker of other birds) may be played by the same character. As Alan Deyermond has noted, "Calisto, Melibea, Celestina, and others are alternately or simultaneously hunter and quarry in the hunt of lust or avarice or power" ("Hilado": 6). As I will attempt to demonstrate, the avian imagery associated with these characters is not constant; it changes to reflect their position relative to the other characters, as predator or prey.

Celestina can be identified with the milano or kite, which is both predator and prey.? Her pursuit of Melibea, whom she attacks in the safety of her own home, in the presence of her mother, is akin to that of the "groseros milanos" (16) alluded to in the prologue, which "insultan dentro en nuestras moradas los domésticos pollos y debajo las alas de sus madres los vienen a cazar" (16). ${ }^{8}$ There is a biblical precedent for this image: Jesus (Matthew 23: 37) compares himself to a hen and Jerusalem to a chicken which refuses to seek shelter under its mother's wing. Here the chicken is about to commit a grave crime (the crucifixion) and desert the mother hen (Christ). Melibea too is about to yield to temptation. ${ }^{9}$ Although the kite was not mentioned in this passage, it was named and identified with the Devil in patristic and medieval Biblical exegesis (Garci-Gómez 14; Rowland Birds 93-94) and it is he whose aid Celestina has enlisted in order to effect the seduction of Melibea.

As might be supposed from Rojas's epithet "grosero", the social status of the milano matches that of Celestina. Unlike hawks and falcons, the kite was not greatly esteemed as a bird of prey and was not included among the noble 
hunting birds such as the eagle or the neblí. Juan Manuel observed that: "estos milanos [...] mas son para ser cazadas que para cazar" (Libro del caballero 251). However, they were still dangerous predators. Chickens in particular had to be guarded against kites and a special basket was used, a pollera, "un género de cesto $\sin$ suelo, recogido de boca, adonde ponen los pollitos quando son pequeños, porque no se los lleve el milano" (Covarrubias Horozco 876). Rojas's image, then, would no doubt have been vividly brought to life in the mind of the contemporary reader or listener by the recollection of this practice, or the experience of losing chickens to kites. ${ }^{10}$ Another characteristic of the milano is that it in turn may become the target of larger birds of prey, "ella misma prision de las demás aves de altanería" (Covarrubias Horozco 805), and this would reinforce the perception of Celestina as an ignoble, dangerous and yet also vulnerable bird of prey. Celestina's vulnerability is emphasised still further when she describes herself as a "una gallina atada" (300) shortly before being murdered.

Although Celestina and Melibea are generally depicted as predator and prey, they are at other times portrayed as members of the same species, hens. The associations of the hen are positive when they refer to the Christ-hen, but negative when used to describe wandering women. Melibea first appears as a hen when Celestina states: "no es ésta, si a Dios ha placido, la primera a quien yo he hecho perder el cacarear" (100). The verb "cacarear" signifies "Dar voces repetidas el gallo o la gallina" (Diccionario de la lengua española 348). A cockerel appears in the same speech, being cursed by the ladies who have given themselves over to love: "Si de noche caminan, nunca querrían que amaneciese; maldicen los gallos porque anuncian el día" (100). These women, who have taken control of their own sexuality, naturally wish to rebel against the cockerel that places a limit on their sexual excesses by crowing to indicate the coming of day. The cockerel, as in the case of St Peter, was also "the symbol of the call to repentance" (Rowland Birds 22), a call which these women would reject. ${ }^{11}$ Celestina first mentions hens to Melibea by way of a refrán, "viva la gallina con su pepita" (116). This is in the context of the disadvantages of old age and the saying is innocuous enough. According to the Refranero Español, "Se dice de los enfermos y de las cosas necesarias, aunque tengan inconvenientes" (515). Nonetheless, another refrán, mentioned by Covarrubias Horozco, explains the cause of the pepita: "«De dónde la vino a la gallina la pepita?", quando alguna muger ha hecho por donde tenga ruin fama" (622). Women are compared to hens in two other refranes:

«La muger y la gallina, hasta casa la vezina»; dizen que si se alexa de su propia casa la gallina, que no sabe bolver a ella. Este proverbio da a entender quanto importa que las mugeres no sean andariegas, por lo que les puede suceder fuera de sus casas. Otro proverbio ay, que es casi el mismo: «La muger y la gallina, por andar se pierden ayna» (Covarrubias Horozco 622) 
and Gonzalo Correas registers the phrase "Más puta que una gallina" (296), which states the matter even more bluntly.

Even if Rojas did not intend any allusion to these particular refranes, it was not unusual to compare women to hens in order to highlight the dangers of them wandering in both a literal and moral sense. As we have seen, Celestina mentions that ladies who lose their morals "de noche caminan" and she herself is renowned for being a trotaconventos, so there is certainly a nexus of ideas in existence linking women, hens, and wandering, which finds echoes in Celestina.

Women of various social types are portrayed as being involved in the breeding of hens. Elicia, on putting off her mourning, declares that she will make herself beautiful once more and carry out domestic chores, one of which is hen-keeping: "Quiero aderezar lejía para estos cabellos, que perdían ya la rubia color y, esto hecho, contaré mis gallinas" (350). Areúsa imagines a conversation a woman might have with a friend, which includes the question " $¿ C u a ́ n t a s$ gallinas crías?" (236), and contrasts this with the angry statements made to a serving-maid by her mistress, "Ven acá, mala mujer, la gallina habada no parece; pues búscala presto; si no, en la primera blanca de tu soldada la contaré" (238). This is a reflection of social reality, since most women probably did have some knowledge and practice of hen-rearing, "Por la mayor parte cuasi no hay mujer que no sepa criar gallinas" (Alonso de Herrera 295). ${ }^{12}$ In addition to breeding hens, several women are compared to hens. As we have already seen, Celestina describes herself as a hen before she dies, Melibea is linked with them when on the verge of sexual initiation, and loose-living women could be referred to as hens. Unsurprisingly, the two rameras are also associated with them. Elicia, as we have seen, keeps them, Areúsa has spoken about them and Celestina mentions them on learning of the latter's early bed-time:

AREU. -(¡Válala el diablo a esta vieja, con qué viene como huestantigua a tal hora!) Tía, señora, ¿qué buena venida es ésta tan tarde? Ya me desnudaba para acostar.

CEL.-¿Con las gallinas, hija? (188).

The fact that the hen associations apply equally to Melibea, Areúsa, Elicia and Celestina demonstrates the breakdown of barriers between the two levels of society represented in Celestina. ${ }^{13}$ It also blurs the distinction between courtly love and another type of sexual relationship that occurs outside marriage, namely prostitution.

Like the hen, the cockerel had both positive and negative connotations. He was, "In medieval times [...] the good Christian, saint or priest" (Rowland Birds 21) and, as we have seen above, could symbolise the call to repentance. 
The cockerel's generosity is alluded to by Celestina: "Ninguna cosa el gallo come que no participe y llame las gallinas a comer de ello" (122-124) and this coincides with the view that "when the cock gave food to his hens the bird was like the loving husband or the liberal man" (Rowland Birds 25). Quite different symbolism, however, is involved when Pármeno is linked to the cockerel. The connection was first suggested when Celestina promised Sempronio she would corrupt Pármeno and bring him into sympathy with them: "Yo te le traeré manso y benigno a picar el pan en el puño" (60). James Mabbe, in his translation of 1631, expressed the phrase as: "I will make the slave so tame and so gentle, that I will bring him like a bird to pick bread from my fist" (61, my italics). ${ }^{14}$ As birds of prey eat meat, not bread, the kind of fowl alluded to would appear to be a domestic one. The location of this reference to the tame bird which will eat from Celestina's hand may have added significance in the light of the refrán "El moço y el gallo un año" which according to Covarrubias Horozco signified that "en siendo uno criado viejo es aragán, y dize que ya ha servido harto y se haze insufrible, especialmente si el señor le ha entregado la llave de sus secretos" (625).$^{15}$ Celestina compares Pármeno, who knows Calisto's "secretos", to the bird in order to express her wish to corrupt him and turn him into a disloyal servant. The irony is that Pármeno, whose loyal advice includes the warning "a quien dices el secreto, das tu libertad" (84), is described by Calisto as a "mal criado" (86) and is compared unfavourably to Sempronio: "Cuanto remedio Sempronio acarrea con sus pies, tanto apartas tú con tu lengua, con tus vanas palabras; fingiéndote fiel, eres un terrón de lisonja, bote de malicias" (86). These accusations of faithlessness and flattery would be more truthfully directed at Sempronio, but it is he, not Pármeno, that Calisto describes as "llave de mi vida" (60) and "leal" (84). It is not until Pármeno, at Areúsa's house, has given his promise to "ser muy amigo de Sempronio y venir en todo lo que quisiere contra su amo en un negocio, que traemos entre manos" (198) that Celestina's ambition with regard to Pármeno is fulfilled and she metaphorically transforms him into a "gallillo, barbiponiente [...] que en tres noches no se le demude la cresta" (200). ${ }^{16} \mathrm{He}$, like the cockerel, will henceforth neglect his master's interests. In so doing, he perverts the positive cockerel trait of generosity. He invites Areúsa, Sempronio, Celestina and Elicia to a meal, but as he makes clear, he does so at his master's expense since he does not intend paying for the food:

En casa llena presto se adereza cena. De lo que hay en la despensa basta para no caer en falta. Pan blanco, vino de Monviedro, un pernil de tocino, y más seis pares de pollos, que trajeron estotro día los renteros de nuestro amo. Que si las pidiere, haréle creer que los ha comido (214).

If Pármeno cannot be said to embody any of the positive qualities of the cockerel, he takes on fully the cockerel's more negative associations with lust and aggression. It is through the offer of Areúsa's sexual favours that Celestina 
secures Pármeno's promise, and the young cockerel to which Celestina compares him was known as a very lascivious bird:

esta ave es luxuriosa, y con tanta furia que el hijo mata al padre sobre cuál de los dos subirá la gallina, aunque sea la que engendró su güevo, de donde vino que entre otros animales que echan en el odre, o cuba, del parricida, uno dellos es el gallo (Covarrubias Horozco 624; see also Rowland Birds 26-27).

Pármeno's involvement in Celestina's murder is perhaps also anticipated here, since she has stood in loco parentis to him. Of course the parallel is not complete, since she is not a father and the dispute is ostensibly over a gold chain. Celestina, however, believes that there may be a sexual motive behind Pármeno and Sempronio's aggression:

No cierto de la necesidad que tenéis de lo que pedís, ni aun por la mucha codicia que lo tenéis, sino pensando que os he de tener toda vuestra vida atados y cativos con Elicia y Areúsa, sin quereros buscar otras, movéisme estas amenazas de dinero, ponéisme estos temores de la partición. Pues callad, que quien éstas os supo acarrear, os dará otras diez, agora que hay más conocimiento y más razón y más merecido de vuestra parte. Y si sé cumplir lo que prometo en este caso, dígalo Pármeno (298).

It seems no coincidence that although Sempronio denies this, Pármeno does not. Celestina, as the milano, had been the ravisher of chickens and in a comment she appends to her description of Pármeno as a "gallillo" states that she had preyed on cockerels too, "De éstos me mandaban a mí comer en mi tiempo los médicos de mi tierra, cuando tenía mejores dientes" (200). The avian imagery shows a cycle of one bird preying on another, only to become a victim itself at a later date.

Calisto is from the very beginning associated with his lost falcon: "Entrando Calisto en una huerta en pos de un halcón suyo, halló ahí a Melibea" (22). Although he also owns a gerifalte, that is, a gyrfalcon or Falco rusticolus, this bird has less bearing on his destiny and we know of it only through Sempronio. Calisto's "halcón" has often been referred to as a "hawk", despite the fact that the bird named in the argumento del primer auto is clearly a falcon. ${ }^{17}$ Pármeno is more specific than the argumento of Act $\mathrm{I}$, since he describes the bird as "el nebli" (86) instead of using the generic term "halcón". There is no conflict between the two names as the nebli is a type of falcon, the peregrine falcon, Falco peregrinus, now better known in Spanish as the halcón común. ${ }^{18}$ The "gavilán" mentioned in the prologue is the sparrow-hawk, Accipiter nisus. The non-Castilian texts adduced by Charles B. Faulhaber, E. Michael Gerli 
("Calisto's Hawk"), María Rosa Lida de Malkiel and Donald McGrady ("The Hunter") seem to refer almost exclusively to falcons, whereas the Castilian texts they mention present a mixture of birds which include "azores" as well as "falcones". ${ }^{19}$ The "açor" or "azor" is the goshawk, Accipiter gentilis. ${ }^{20}$ That non-Hispanic texts prefer the falcon over the goshawk whereas texts from the Peninsula refer to both falcons and goshawks reinforces the suggestion made by Cummins that the goshawk was held in much higher esteem in Spain than elsewhere:

el azor parece tener un prestigio algo más grande en España que en otros países. En la epopeya y el romancero españoles el azor aparece con frecuencia [...]. En Inglaterra, la caza con el azor no es apropiada para los nobles (López de Ayala 212).

Despite the confusion surrounding Calisto's lost bird, there are enough examples of both falcons and hawks in the examples adduced to demonstrate that, for symbolic purposes, the two were interchangeable in Spanish literature, either in the context of the hunt of love and/or where the bird represents a "life-symbol" (McGrady "Calisto" 96). ${ }^{21}$ The symbolism of the hawk, a sign of "aggressive male sexuality" (McGrady "Calisto" 94), has long been recognised in the context of Calisto, and McGrady ("The Hunter" and "Calisto") has demonstrated that the loss of the hawk is often a precursor of the death of its male owner.

Although the sexual symbolism and the overtones of impending doom apply equally to hawk and falcon, the naming of the particular species of falcon lost by Calisto is significant since there was a difference in status between the nebli and other falcons. The neblí was very highly prized, "son aves muy preciadas de príncipes y grandes señores" (Evangelista 7) and its character was considered one of the noblest, "es el mas noble e mas gentil de todos" (López de Ayala 51). ${ }^{22}$ That Calisto owns such a bird says much for his social status and, if it represents him, suggests that he too is one of the noblest of individuals, as indeed is stated in the argumento: "Calisto fue de noble linaje, de claro ingenio, de gentil disposición, de linda crianza" (22). Unfortunately Calisto, despite his "linda crianza" imitates his falcon and "escapes control" (Weinberg 138). In his obsession with his prey (Melibea), he forgets his upbringing. Thus the expectation of the perfect courtly lover raised by the initial description of him is soon dashed. ${ }^{23}$ It may therefore be that the reference to the noblest of falcons in Act II, coming as it does after Calisto's "adoration" of Celestina, shows how far Calisto has been degraded by his obsession with Melibea. In fact, the bird imagery serves to suggest a similarity of motive between Calisto and Celestina, for although there is some difference between Calisto (neblí) and Celestina (grosero milano), both are birds that attack Melibea with predatory intent. 
Sempronio is associated with the "gerifalte" with which he first appears, though it may be that he mentions it merely as an excuse:

CAL.-jSempronio, Sempronio, Sempronio! ¿Dónde está este maldito?

SEMPRONIO.- Aquí estoy, señor, curando de estos caballos.

CAL.Pues, ¿cómo sales de la salà?

SEMP.-Abatióse el gerifalte y vínele a enderezar en el alcándara.

CAL.-jAsí los diablos te ganen! (26). ${ }^{24}$

If so, this is the first example of Sempronio's tendency to seek to deceive his master, a trait that characterises him and which fits well with the spurious etymology of gerifalte given by Evangelista: "Halcon girifalte se dice por halcon que jura falso y no es creído, y tales son ellos" (4). This opinion of the bird is given in a humorous context but it reflects a low opinion of the bird's character which complements that of Pero López de Ayala, who was most certainly in earnest. ${ }^{25}$ The latter informs the reader that the gerifalte is cowardly and difficult to train: "no ha dubda que los girifaltes, como quier que despues que son fechos son muy buenos falcones, pero al comienço son graves de fazer. Ca de su naturaleza son covardes" (68). ${ }^{26}$ During the course of Celestina we see that Calisto provokes Pármeno's disloyalty, and it may be that he must also bear some blame for not correcting Sempronio's behaviour. ${ }^{27}$ Sempronio demonstrates his cowardice when, along with Pármeno, he abandons his master outside Melibea's house. ${ }^{28}$ The gerifalte was, however, an efficient and dangerous killer, a fact which agrees well with Sempronio's involvement in the murder of Celestina:

devedes saber que el girifalte que se da a bien mata muy mas ligero e mejor garça o grua, e la prision a que fuere lançado, que ninguno otro falcon, ca la garça mata muy alta, e al sobir non faze tantos tornos como el nebly, e va mas derecho en sus buelos, e como quier que por la su grandeza salga pesado de la mano, pero desque comiença a cavalgar el ayre toda via cobra mayor ligereza (López de Ayala 72).

Girifaltes possessed other traits, including being "muy pesadas e muy afogadizos e antojadiços de su naturaleza, e quexosos" (López de Ayala 159); most of these are characteristics which apply equally well to Sempronio.$^{29} \mathrm{He}$ angers quickly (as in the dialogues he has with Pármeno, before he is convinced of their friendship) and according to Charles F. Fraker "Sempronio's irresoluteness is distinctive: it sets him apart from other characters" (136). Of the six types of falcon identified in the Libro de la caça de las aves, four, including the gyrfalcon, are described as "villanos, asy como quien dize falcones bastardos, o fornezinos, e solamente al nebly e bahari llaman falcones gentiles" (López de Ayala 61). That both master and servant (who admits to having been "hecho otro Calisto" [232] by love) are represented by birds used in falconry suggests 
the similarities between them, yet class distinctions are also inherent in the authors' choice of species. The bird-catching imagery provides us with another analogy between Sempronio and Calisto. When Celestina attempts to convince Sempronio that he requires fewer material possessions than she does, she states that apart from a few items of clothing he needs only:

un arco para andarte de casa en casa tirando a pájaros y aojando pájaras a las ventanas! Mochachas digo, bobo, de las que no saben volar, que bien me entiendes. Que no hay mejor alcahuete para ellas que un arco, que se puede entrar cada uno hecho mostrenco, como dicen: en achaque de trama, etc (144).

This continues the imagery of women as small, vulnerable birds, but here the predator is human rather than winged. Celestina's image suggests that Sempronio's bow could function in a similar manner to Calisto's falcon inasmuch as it provides the opportunity for a man to enter the presence of a secluded woman. ${ }^{30}$

The partridge would have been a suitable prey both for birds trained to falconry and for human hunters. It was thought that:

Perdiz es una ave en pos que van los caçadores muy de grado, por la bondat de su carne. Mas es mucho baratadera de luxuria, ca por la calentura de su luxuria lidian algunas vegadas los maslos entre sy por la fenbra, \& olvidan la conoçençia de la natura, en tal manera que se allegan los maslos \& olvidan las fenbras. \& dizen muchos que quando la fenbra camia su natura conçibe de la parte onde viene el viento onde es el maslo (The Medieval Castilian Bestiary 32-33).

Its reputation in the bestiary meant that this bird could be used to describe both males and females who were involved in sexual activity. When Celestina encourages Areúsa to take a second client, she describes the men as partridges: "una perdiz sola por maravilla vuela" (196). Given the suspicion that Calisto's emotions towards Melibea may be motivated by lust, it seems highly suggestive that Sempronio should describe Calisto as an ensnared partridge: "no puedes ver de encandelado, como perdiz con la calderuela" (1987: 216). In the Tragicomedia version Pármeno comments "El falso boezuelo con su blando cencerrar trae las perdices a la red" (270), which expresses his suspicion that Melibea means to trap Calisto as one would trap a partridge. ${ }^{31}$ The image of Melibea as a partridge-catcher is not the only one in which the male is the vulnerable bird. As Elicia explains, cosmetics can snare men as surely as birds are caught in bird-lime: "No es otra cosa la color y albayalde, sino pegajosa liga en que se traban los hombres" (350). The fact that the character represented by the predatory neblí can also be symbolised by the lustful and easily ensnared par- 
tridge is not a flaw in the imagery but rather demonstrates that different birds are used to represent different aspects of the character's personality.

As we have already seen, this is also the case with Celestina, who is both milano and gallina. I would like to suggest that although Melibea is a chicken to Celestina's kite and her hen associations place her on a par with other women who are sexually active outside marriage, she is a partridge to Calisto's falcon. Given that Sempronio and Pármeno's suspicions of Melibea are unfounded, it would seem likely that although the partridge can represent Calisto's lust, it can also represent Melibea when Calisto is in a predatory mood. The partridge is often used to symbolise a woman and is a noble bird (unlike the hen) often depicted as the prey of a falcon or hawk (a male lover), as the dialogue of the noble lady with the commoner in Andreas Capellanus's De amore demonstrates:

Even if I were so to take leave of my senses as to be impelled by your words to assent to your proposal, your heart could not cope with such lofty tasks. Could a kestrel ever prevail over a partridge or a pheasant by its own strength? This booty is suitable for falcons or hawks to seize; it should not be disturbed by the petty-spirited kite (Walsh 63). ${ }^{32}$

It is significant that the kite (milano) is contrasted negatively with falcons since these are the birds used by Rojas to represent Celestina and Calisto. Calisto, whose falcon causes the meeting with Melibea, pursues her avidly for some time and, in the Tragicomedia version, directly before consummation treats her like a bird for eating, "Señora, el que quiere comer el ave, quita primero las plumas" (378). ${ }^{33}$ The partridge, unlike the hen, is a bird after which a falcon might fly and it is described by falconers as a bird which can exercise the bird of prey:

es muy bueno al girifalte [fazerle] bolar la perdiz, por quanto la perdiz buela luengo trecho, e saca mucho el buelo al falcon e a qualquier ave que la sigua (López de Ayala 72-73).

This flight, which exercises the hawk, may, when the birds are being used as a metaphor for lovers, refer to the time it takes the male lover to win his beloved. The flight is also described as arousing the hunger of the hunting-bird and in this case specific mention is made of the neblí, the same species as is flown by Calisto:

al tu nebly pollo fazle bolar algunas vezes sobre las perdizes, ca los faze la tal bolerya de perdiz muy altos e muy redondos, e toman los falcones en ello gran golosina e gran sabor (López de Ayala 96). 
Calisto is similarly hungry for Melibea.$^{34}$ Sosia uses a culinary metaphor to describe their sexual activities: "con su pan se la coma, que bien caro le cuesta; dos mozos entraron en la salsa de estos amores" (316) and we have already seen that in the Tragicomedia version Calisto describes Melibea as a bird which requires plucking. ${ }^{35}$ Furthermore, he mentions her "lindas y delicadas carnes" (314) and while this could be on purely aesthetic grounds, there are overtones which suggest that he views her as a tasty morsel to be consumed. Deyermond states that "Tal frase sería inocua en otro contexto, pero los comentarios de los criados crean un contexto en el cual 'carnes' sugiere 'carne para comer' " ("El que quiere comer" 295). ${ }^{36}$ If Melibea is intended to be viewed as a partridge it is not surprising that Calisto should be eager to eat her, since partridges were particularly appreciated for their tender flesh, being included in a list of "buenas carrnes" (Arte complida 41r) in one medical text and among those which are described in another as "de digerir muy faciles, y ni demasiadamente calientes, ni corruptibles, sino en todo templadas" (Discurso breve 24r). ${ }^{37}$

Partridges are also among the fare that the Archipreste de Talavera describes in his section on how love causes the fifth mortal sin, gluttony:

Deste non se puede escusar el que ama o es amado de muchos excesivos comeres e beveres en yantares, cenas, e plaseres con sus coamantes, comiendo e beviendo ultra mesura; que ally non ay rienda en conprar capones, perdizes, gallinas, pollos, cavritos, ansarones carnero e vaca para los labradores - , vino blanco e tinto, jel agua vaya por el río!, frutas de diversas guisas, vengan doquiera, cuesten lo que costaren (Martínez de Toledo 106). ${ }^{38}$

The scene, with similar meats and the same abundance of wine, recalls those of Celestina's heyday:

enviaban sus escuderos y mozos a que me acompañasen, y apenas era llegada a mi casa, cuando entraban por mi puerta muchos pollos y gallinas, ansarones, anadones, perdices, tórtolas, perniles de tocino, tortas de trigo, lechones. Cada cual, como lo recibía de aquellos diezmos de Dios, así lo venían luego a registrar, para que comiese yo y aquellas sus devotas. ¿Pues vino, no me sobraba? De lo mejor que se bebía en la ciudad (242).

As well as being good to eat, the partridge had the well-known sexual connotations mentioned above, and it was perhaps for this reason that it became associated with the tax that prostitutes had to pay in order to remain within a town. Originally the tax was paid in real birds: "The harlots of Ledesma, in return for a weekly donation of partridges, received the protection and supervision of the town's judge" (Dillard 196). It is possible that this was the 
source of the term "ley de perdices" which was given to the tax in the fifteenth century, although by this stage it was paid in coin (Lacarra 38-39). In Celestina partridges are mentioned in the context of prostitution and it may even be that in the case mentioned above they form an inverted tribute whereby Celestina, instead of having to pay partridges for providing prostitutes, receives them. A more obvious irony is that this food is clearly described as being provided out of the tithes received by her clerical clients, tithes which should have been spent on the upkeep of the church and on works of charity, not on Celestina's rather dubious "devotas". No explicit connection is made between prostitutes and partridges, but it seems significant that Celestina recommends "humo de plumas de perdiz" (192) as a possible cure for Areúsa's uterine pains. Given the partridge's nature and Celestina's other suggested cure, intercourse with Pármeno, this would appear to have sexual overtones.

It would seem therefore that partridge imagery allows comparisons to be made between Melibea and the prostitutes in the same way as the chicken and hen imagery made Melibea into the same species as Celestina, Areúsa and Elicia. ${ }^{39}$ The two types of birds are related, for although one is wild and the other domesticated they are both members of the order galliformes (Perrins 100). The similarities had been noted by the fifteenth century: Juan de Aviñón's Sevillana medicina states that the partridge "es llamada gallina montesina" (Fradejas Lebrero "Tres notas" 51). ${ }^{40}$ Calisto, as a partridge, is akin to Areúsa's clients. The ultimate effect of the use of these metaphors is to degrade Melibea and Calisto's love and place it on the same plane as that of the mozos and prostitutes. They therefore complement more obvious comparisons such as the one Sempronio makes on hearing that Pármeno has become involved with Areúsa: "Reírme querría, sino que no puedo. ¿Ya todos amamos? El mundo se va a perder. Calisto a Melibea, yo a Elicia, tú de envidia has buscado con quien perder ese poco de seso que tienes" (208). Even more degrading to Calisto and Melibea are Celestina's derogatory comments regarding ladies, in which she insinuates that once they lose their shame they are as sexually active as prostitutes:

Coxquillosicas son todas; mas, después que una vez consienten la silla en el envés del lomo, nunca querrían holgar; por ellas queda el campo. Muertas sí; cansadas no (100). ${ }^{41}$

Rojas compared the animal world with the life of human beings in his prologue and Calisto stated his willingness to be like an animal, "si el de purgatorio es tal, más querría que mi espíritu fuese con los de los brutos animales, que por medio de aquél ir a la gloria de los santos" (30). Celestina restates the similarities between humans and the natural world in her first conversation with Pármeno:

es necesario que se turbe con la dulzura del soberano deleite, que 
por el hacedor de las cosas fue puesto, porque el linaje de los hombres se perpetuase, sin lo cual perecería. Y no sólo en la humana especie; mas en los peces, en las bestias, en las aves, en las reptilias; y en lo vegetativo algunas plantas han este respecto (64).

The avian metaphors take us further than a levelling between social classes: they suggest that the pursuit of sexual pleasure dehumanises Celestina and the lovers. ${ }^{42}$ With a generalisation by Celestina the comparison between the lovers and birds extends beyond the boundaries of Celestina and its application to Calisto, Sempronio and the rest, to touch the "muchedumbre de galanes y enamorados mancebos" (6) for whose edification and instruction on the dangers of love Rojas composed the work:

estos novicios amantes, que contra cualquiera señuelo vuelan sin deliberación, sin pensar el daño que el cebo de su deseo trae mezclado en su ejercicio y negociación para sus personas y sirvientes (92) ${ }^{43}$

It is significant that a character's linguistic metamorphosis into a bird is often prompted by becoming a lover: Calisto loses his heart to Melibea as his falcon disappears into her garden; Pármeno is metamorphosed into a cockerel when he is on the verge of consummating his relationship with Areúsa; the allusions linking Melibea and birds are spoken by Celestina as she plots the former's seduction and by Calisto as he carries it out; even Sosia, when flattered by Areúsa, acquires wings: "en verse medrado con calzas y capa, sálenle alas y lengua" (352) ${ }^{44} \mathrm{Of}$ all of them, as of the ant in the verse prologue, it can be said "En las nuevas alas estaba su daño" (8) since, with the exception of Sosia, who loses his master, they all die. As Sempronio, Celestina, Areúsa and Elicia are already deeply involved in matters concerning carnal love long before Calisto loses his falcon in Melibea's garden, there can be no question of their metamorphosing into birds, but they are clearly shown to be associated with them and Sempronio and Celestina, like the new lovers, also die. The avian imagery is therefore used to represent the "hunt of love." Even where the predator is a human hunter, the foolish lover, either male or female, who is the prey, may still be represented as a bird. In addition, the shifts between hunter and hunted, predator and prey which exist in the text underscore the sudden changes of fortune, which can occur just when the characters least expect them. Despite the fact that the identification of the lovers and prostitutes with birds levels social differences and even dehumanises the protagonists, it is nevertheless clear that different birds have different connotations and that the particular bird or birds which are chosen to represent an individual character tell us much about their personality. However, all of them are involved in the hunt of love and to that extent one may truly say that Celestina and the lovers are birds of a feather. ${ }^{45}$ 


\section{NOTES}

1 There was a long-running controversy in Celestinesca concerning methods used to catch partridges, focusing on the phrases "encandelado, como perdiz con la calderuela" (216) and "El falso boezuelo con su blando cencerrar trae las perdices a la red" (270). See: Dorothy S. Severin; Keith Whinnom ("Dr Severin"); David Hook ("Andar a caça" and "Pármeno"); Dennis P. Seniff; E. Michael Gerli ("A Propos"); Jacques Joset; José Fradejas Lebrero ("Tres notas" 51-52; "Cazar aves"); José Manuel Fradejas Rueda. For the lasciviousness of partridges (especially in relation to Florencia Pinar) see Alan Deyermond ("The Worm") and Whinnom (La poesía 31-32). For Calisto's falcon see María Rosa Lida de Malkiel (200-206); Raymond E. Barbera (5-9); F. M. Weinberg (137-138; 141-142); Charles B. Faulhaber; Gerli ("Calisto's Hawk"); Miguel Garci-Gómez; Donald McGrady ("Calisto" and "The Hunter").

${ }^{2}$ Another animal image which illustrates the dangers of sexual love and which appears throughout the work is that of the viper (Deyermond "Symbolic Equivalence").

${ }^{3}$ All quotations from Celestina are from Dorothy Sherman Severin's 1987 edition.

${ }^{4}$ Juan Manuel describes dogs and birds being used together in the hunt in his Libro de la caza: "los falcones caçan las grúas derribándolas muchas vezes, así que las más vegadas tardan mucho ante que sea muerta. Et an los omnes muy grant plazer quando veen que la apartan los falcones entre las otras, et cómo la derriba[n] et cómo la faze[n] estar penada et cómo acorren los canes a los falcones por la tomar o por la levantar" (9-10, my italics).

${ }^{5}$ Covarrubias Horozco adds that "Yo pienso que en esto quisieron sinificar la hediondez destas malas viejas, que por avaricia echan a perder la gente moça y la ensuzian, como se cuenta de las harpías, a las quales davan esta forma" (509). Given that Covarrubias Horozco dedicates one entry in his Tesoro to Celestina (401), he may have had her in mind when he made this mention of "viejas" and their "avaricia", since avarice is a vice particularly associated with her. It is also possible that Rojas had previously made the connection between the feathered witch and the harpies, since the latter appear in Celestina's invocation of the Devil (104) in the Tragicomedia version. The association with honey might cause a contemporary reader or listener to associate Celestina (who has been covered in it) and Melibea (whose name suggests it). Later Celestina, in comparing herself to a bee, states that she has created Melibea's sweeter attitude: "La mayor gloria que al secreto oficio de la abeja se da, a la cual los discretos deben imitar, es que todas las cosas por ella tocadas convierte en mejor de lo que son. De esta manera me he habido con las zahareñas razones y esquivas de Melibea. Todo su rigor traigo convertido en miel" (154). For Celestina as a bee see Deborah Ellis (6-8).

${ }^{6} \mathrm{~A}$ more natural cause for feather-loss was moulting. While there is no 
evidence that Calisto, as a neblí, is undergoing this process, it is interesting to note that the moulting falcon was to be kept in a darkened "casa" to which the falconer should ensure "que non entre la lunbre sy non una ventana, que la abras quando quisieres" (López de Ayala 176). Calisto's order to Sempronio: "Cierra la ventana y deja la tiniebla acompañar al triste y al desdichado la ceguedad" (26) would create similar conditions.

${ }^{7}$ Some critics have associated Celestina with other birds of prey: "Celestina era, ¿qué duda cabe?, gavilán, milano, neblí, halcón, cualquiera de aquellas groseras aves del prólogo" (Garci-Gómez: 16). Weinberg, speaking of Calisto's nebli states that "The bird further stands for Celestina, incarnation of rapine and lust, who preys upon young people, particularly on the tender maidens of the town" (138). As I hope to show, the birds of prey, milano, nebli and gerifalte, are paired with Celestina, Calisto and Sempronio respectively, according to the birds' differing associations.

${ }^{8}$ The metaphor is used elsewhere. In the Libro de Alexandre:

Quando asomo Archiles a vnos canpos planos

conosçerienlo luego en los jestos loçanos

asi se quebrantaron Etor e los troyanos

commo fasen los pollos quando sienten milanos (122).

9 The image of the Christ-hen, although it reflects ironically on Alisa's position, does not describe her: whereas the Christ-hen wishes to protect its chick and is abandoned by it, Alisa proves to be a negligent parent who leaves her chick unprotected.

${ }^{10}$ Gabriel Alonso de Herrera in his early sixteenth-century Obra de agricultura states that: "ninguna costa es tan grande que iguale con la pérdida y enojo que trae ver llevar los pollos a los milanos" (295).

${ }^{11}$ Covarrubias Horozco states that "el symbolo del gallo [...] sinifica los perlados de la Yglesia y los predicadores, con cuya dotrina se han de reduzir los malos y distraydos, y los que no los quisieran oyr serán semejantes a los sybaritas, gente olgazana y viciosa, que aviendo desterrado de su república las artes mecánicas y todo lo que no fuesse plazer, descanso y vicio, desterraron también los gallos" (623).

${ }^{12}$ In the memorable passage in the Corbacho where a woman laments the loss of an egg, she does so partly because she imagines the birds she could have bred from it: " $\mathrm{A} y$, huevo mío de dos yemas, que para echar vos guardava yo! ¡Ay, huevo! ¡Ay, qué gallo e qué gallina salieran de vos! Del gallo fiziera capón que me valiera veynte maravedís, e la gallina catorze. O quiçá la echara e me sacara tantos pollos e pollas con que pudiera tanto multiplicar que fuera causa de me sacar el pie del lodo" (Martínez de Toledo 124, my italics).

${ }^{13}$ As Deyermond has observed, there are "dos clases, una aristocracia y la plebe de criados y prostitutas que depende económicamente de ella" ("Divisiones" 4).

${ }^{14}$ Blay and Severin identify the creature which will come to eat from Celestina's hand with the ass she had mentioned previously as part of the refrán 
"do vino el asno verná el albarda" (Rojas 60). They therefore conclude that Celestina: "threatens to turn him [P'ármeno] into an ass who eats from her hand" (12). Mabbe believed the creature referred to was a bird and Rojas's use of the verb "picar" would tend to suggest a beaked animal.

${ }_{15}$ The Refranero Español's definition is similar: "Dice que los criados no deben conservarse mucho tiempo porque toman demasiada intimidad y merced a ella no cumplen sus deberes como debieran" (331).

${ }^{16}$ The promise is omitted in the Tragicomedia version but even without it, it is clear that by accepting Celestina's offer of Areúsa he has tacitly agreed to join Celestina and Sempronio against Calisto.

${ }^{17}$ Barbera alternates between "hawk" and "falcon". Faulhaber's article is named "The Hawk in Melibea's Garden". McGrady writes of "Pármeno's reference to the lost hawk in Act II" ("Calisto" 96). Gerli mentions that "The bestiaries of the Middle Ages portray the hawk as a bold, determined bird who takes its name, accipiter (robber), from accipiendo (taking), related to capiendo (seizing), because it snatches greedily from others" ("Calisto's Hawk" 85-86). This is no doubt true, but it may not be of such relevance to the neblí, the etymology of whose name had rather different connotations (see below).

${ }^{18}$ Blay and Severin write: "Calisto loses a falcon in Melibea's garden (or is it a neblí, a hawk, as Pármeno tells us in Act 2?)" (9). They then state that "the falcon more specifically becomes a goshawk" (13). Their mistaken identification of the nebli causes them to postulate a discrepancy in the text. In fact Rojas seems to have been very careful in his use of birds and bird imagery.

${ }^{19} \mathrm{I}$ have not been able to check all these texts in their originals.

${ }^{20}$ For detailed information on the various birds mentioned, as well as their names in Castilian, Latin and English see Roger Peterson, Guy Mountfort \& P. A. D. Hollom. The name "nebli" does not appear in this work, but can be found under "peregrine" (alongside "falcón común") in the Collins Spanish-English English-Spanish Dictionary (469). The nebli is identified as "Falco peregrinus" in Cummins (López de Ayala 209). Whinnom, in his Glossary of Spanish Bird-Names, lists the varying Castilian names assigned to individual birds. The sparrow-hawk is number 122 (48), the goshawk 124 (48), the peregrine falcon 138 (49) and the gyrfalcon 141 (49).

${ }^{21}$ Edith Randam Rogers observes that "In the Romancero it is obvious that several species are mentioned interchangeably to fit rhythm and assonance" $(149$, note). Juan Manuel's view that hunting with falcons is more noble than hunting with hawks is based not on symbolism or literary criteria but on more practical ones concerning how falcons kill the prey: "la caça es cosa noble et apuesta et sabrosa [...] et [...] en la de los falcones se faze más conplidamente que en la de los azores [...]. Ca los falcones matan la garça después que los azores la dexan et por esto es más noble [...] Et porque en todas las cosas en que ha plazer quanto más duran son de mayor plazer, por ende es [de] mayor plazer esta caça con los falcones que con los azores" (Libro de la caza 9).

${ }^{22}$ Although Evangelista's Libro de çetreria is a parody of other, serious, 
treatises on falconry, this description is accurate. Paz y Mélia, in his introduction to the work, describes the enormous prices paid by nobles for the nebli (ii). Pero López de Ayala's work was extremely popular, as Cummins observes: "El éxito del Libro de la caça de las aves en Castilla, Aragón, Italia y Portugal fue destacado. Está evidenciado no solamente por el gran número de manuscritos, sino también por servir de fuente el tratado a sucesores (notablemente a Juan de Sahagún, halconero de Juan II, a Joan Vallés y a Alfonso de Madrigal)" (López de Ayala 17). It seems likely, therefore, that López de Ayala's estimation of the nebli as a particularly noble bird persisted, a supposition supported by the fact that the bird's nobility is acknowledged by Covarrubias Horozco in his description of it as an: "Especie de halcón de mucha estima. Algunos quieren por esto se aya dicho quasi nobli, por su nobleza. Otros dizen aver tomado nombre de la villa de Niebla [...]. Otros quieren se aya dicho quasi nubuli, porque parece bolar sovre las nubes" (825).

${ }^{23}$ For a detailed analysis of Calisto's character, including his egotism and lack of morals see Lida de Malkiel, chapter 12 (347-405). That Calisto is aware that he is falling short of the standards expected of him is amply demonstrated by his debate with himself after the death of Sempronio and Pármeno. He considers remaining hidden in his house, realises that this "Parecerá cobardía" (310) and yet does nothing to salvage his honour.

${ }^{24}$ Falling from their perches did pose some danger to gyrfalcons: "ca como sson pesados, si sse deraman en el alcandara podrian peligrar" (López de Ayala 73).

${ }^{25}$ A dissenting voice is that of Juan Manuel, who on the basis of its size and hunting abilities considered the gyrfalcon the most noble of birds used for falconry: "los falcones con que los omnes usan a caçar son de çinco naturas. La primera et más noble es los falcones girifaltes, et éstos son mayores que todos los otros falcones et más ligeros et caçan más ligeramente et más apuesta, et por ende son más preçiados et es razón que sean puestos primeramente que otros falcones" (Libro de la caza 7-8). Juan Manuel's book survives (in incomplete) form in only one manuscript (Fradejas Rueda Literatura cetrera 27) so we may suppose that it was considerably less influential than "el más famoso y difundido libro de cetrería español" (Fradejas Rueda Literatura cetrera 29), López de Ayala's Libro de la caça de las aves.

${ }^{26}$ The gerifalte seems to have retained its somewhat unsavoury reputation: in the language of the slang of the Siglo de Oro, the word was used as a synonym for "ladrón" (Alonso Hernández 401).

${ }^{27}$ As Sempronio suggests, the master is at least in part responsible for the behaviour of his servants:

CAL. - No seas agora negligente.

SEMP. - No lo seas tú, que imposible es hacer siervo diligente el amo perezoso. (42).

${ }^{28}$ For a more detailed analysis of Sempronio's cowardice see Lida de Malkiel (596-597). 
${ }^{29}$ There are other descriptions of the girifalte in the same work, including details on the young bird: "el torçuelo del girifalte es muy bueno, e sale buen garçero, e es muy ligero, mas es sañudo, e muy delicado, e mal enconico, e ha menester ombre sofrido" (López de Ayala 73). Physically these falcons are: "de su conplision muy calientes, e son muy pesados e muy cargados" (López de Ayala 144). Determining which humour predominates in the gyrfalcon is therefore difficult: although the young bird is described as melancholic, the older is hot (the hot humours were the choleric and the sanguine). Mabbe has Pármeno describe Sempronio as a choleric (179) but this is not in Rojas's text.

${ }^{30}$ Lida de Malkiel's explanation that this part of Celestina's speech seems to show "que Rojas hubiese querido destacar la diferencia entre el tono del comienzo y el tono de su continuación" (202) confirms that she too saw that a parallel was being drawn between the initial occurrence of falconry and this method of bird-hunting. Her attention here is, however, directed towards stylistic considerations rather than characterisation or bird imagery.

${ }^{31}$ There is another bird-catching image in the same speech: "con la mucha gente que tiene, podrá cazar a padres e hijos en una nidada” (270).

${ }^{32}$ As Deyermond ("The Text-Book") has shown, the De Amore was very influential and it is probable that Rojas was acquainted with it.

${ }^{33}$ Deyermond considers that the image here is of Melibea as a hen, not a partridge: "Melibea's body (that hen from which the feathers have been plucked) is 'lo no vendible [...]' " ("Female Societies" 13).

${ }^{34}$ In "El que quiere comer" Deyermond discusses the transformation of Melibea into a "Comestible de lujo, [...] comestible de tan alto precio que sólo el más rico puede comprarlo" (295). See also Eloísa Palafox for the relationship between food, Melibea and sexual experiences.

${ }^{35}$ Given the parallels between Sempronio and Calisto, it is interesting that Celestina accuses the former of an interest in Melibea, and does so by reference to the senses of taste and smell: 'Yo lo veo en ti, que querrías más estar al sabor, que al olor de este negocio' (146). As we have seen, even the smell of their mates was thought to have a powerful effect on female partridges.

${ }^{36}$ In Grisel y Mirabella, Mirabella's flesh is torn apart by lions who then "delas delicadas carnes cada uno contento el apetito" (Flores 363), terms similar to those used by Calisto.

${ }^{37}$ Chicken is also on both lists.

${ }^{38}$ Again, chicken is also on the menu.

${ }^{39} \mathrm{~A}$ further link between partridges, hens and prostitution may be provided by the fact that 'en 1492 los arrendatarios de la mancebía de Jerez se quejan de que los alguaciles cobran el 'derecho de perdices' diez veces al año y dos reales cada vez, y les exigen el pago ilegal del 'derecho de gallinas' “ (Lacarra 39).

${ }^{40} \mathrm{I}$ have not been able to consult this work directly but the edition used by Fradejas Lebrero was published by the Sociedad de Bibliófilos Andaluces in 1885 in Sevilla. The work was written in 1419 but was not published until 1545. 
The quotation is from chapter XXI.

${ }^{41}$ With regard to riding as a euphemism for coitus, see Beryl Rowland (Animals 105). The euphemistic use of 'morir' has been discussed by Whinnom (La poesía 35); this, and the use of the image of the field or 'campo' of combat is discussed by Ian Macpherson.

${ }^{42}$ Deyermond ("Divisiones") shows that Sempronio and Lucrecia have sexual feelings for members of the higher class, while Pármeno is more courtly than Calisto in his attitude towards his lover. The comparison between animals and humans is examined by Blay and Severin who conclude that in Celestina we find 'people whose animal nature leads them into the trap of destruction. The comparison of animal and human behaviour is persistent throughout the work and becomes a dominant theme' (7).

${ }^{43}$ Mabbe translates the passage: 'especially these new lovers, who against any luring whatsoever, fly out to check, they care not whither, without [...] once thinking on the harm which the meat of their desire may by over gorging occasion unto them' (93).

${ }^{44} \mathrm{Mabbe}$ in his translation develops the image further: 'it would give a man wings and tongue, and make him crow, as this cockerel doth' (353).

${ }^{45}$ I am very grateful to $\mathrm{Dr}$ Louise $\mathrm{M}$ Haywood, who read and commented on an earlier draft of this article.

\section{BIBLIOGRAPHY}

ALONSO DE HERRERA, Gabriel. Obra de agricultura. Ed. José Urbano Martínez Carreras. Biblioteca de Autores Españoles desde la Formación del Lenguaje hasta Nuestros Días. 235. Madrid: Atlas, 1970.

ALONSO HERNANDEZ, José Luis. Léxico del marginalismo del siglo de oro. Acta Salmanticensia. Filosofía y letras. 99. Salamanca: Univ. de Salamanca, 1977.

BARBERA, Raymond E. "Medieval Iconography in the Celestina." Romanic Review 61 (1970): 5-13.

BLAY Manzanera, Vicenta, and Dorothy S. SEVERIN. Animals in 'Celestina'. Papers of the Medieval Hispanic Research Seminar. 18. London: Department of Hispanic Studies, Queen Mary and Westfield College, 1999.

Arte complida de cirugía (Cirugía menor), Madrid: Nacional MS. 2165. Transcr. Cynthia M. Wasick and Enrica J. Ardemagni. Electronic Texts and Concordances of the Madison Corpus of Early Spanish Manuscripts and Printings. CD-ROM. Hispanic Seminary of Medieval Studies. 1999.

Collins Spanish-English English-Spanish Dictionary, 3rd ed. Ed. Colin Smith. Glasgow: HarperCollins, 1992.

CORFIS, Ivy A., and Joseph T. SNOW, eds. Fernando de Rojas and 'Celestina': Approaching the Fifth Centenary: Proceedings of An International Conference 
in Commemoration of the 450th Anniversary of the Death of Fernando de Rojas, Purdue University, West Lafayette, Indiana, 21-24 November 1991. Madison: Hispanic Seminary of Medieval Studies, 1993.

CORREAS, Gonzalo. Vocabulario de refranes y frases proverbiales. 1627. Ed. Víctor Infantes. Biblioteca Filológica Hispana. 8. Madrid: Visor Libros, 1992. COVARRUBIAS HOROZCO, Sebastián de. Tesoro de la lengua castellana, $o$ española según la impresión de 1611, con las adiciones de Benito Remigio Noydens publicadas en la de 1674. Ed. Martín de Riquer. Ad litteram. 3. Barcelona: Alta Fulla, 1998. (Facsimile of Barcelona: Horta, 1943).

DEYERMOND, Alan. "Divisiones socio-económicas, nexos sexuales: la sociedad de Celestina." Celestinesca 8.2 (1984): 3-10.

-.-. " 'El que quiere comer el ave': Melibea como artículo de consumo." Vol. 1. Estudios románicos dedicados al prof. Andrés Soria Ortega en el XXV aniversario de la Cátedra de Literaturas Románicas. Ed. Jesús Montoya and Juan Paredes Núñez. Granada: Univ., 1985. 291-300.

--.. "Female Societies in Celestina." Corfis and Snow 1-31.

-.. "Hilado-Cordón-Cadena: Symbolic Equivalence in La Celestina." Celestinesca 1.1 (1977): 6-12.

--. "Symbolic Equivalence in La Celestina: a Postscript." Celestinesca 2.1 (1978): 25-30.

---. "The Text-Book Mishandled: Andreas Capellanus and the Opening Scene of La Celestina." Neophilologus 45 (1961): 218-221.

---. "The Worm and the Partridge: Reflections on the Poetry of Florencia Pinar." Mester 7 (1978): 3-8.

Diccionario de la lengua española, 21st ed. Real Academia Española. Vol. 1. Madrid: Espasa Calpe, 1992.

DILLARD, Heath. Daughters of the Reconquest: Women in Castilian Town Society, 1100-1300. Cambridge Iberian and Latin American Studies. Cambridge: UP, 1984 .

Discurso breve, sobre la cura y preservacion de la pestilencia, Madrid: Nacional R-9186. Transcr. Alejandra Piñeyrúa. Electronic Texts and Concordances of the Madison Corpus of Early Spanish Manuscripts and Printings. CD-ROM. Hispanic Seminary of Medieval Studies 1999.

ELLIS, Deborah. “'AAdiós paredes!': The Image of the Home in Celestina.” Celestinesca 5.2 (1981): 1-17.

EVANGELISTA. Libro de cetrería. Ed. Antonio Paz y Mélia. Sales españoles o agudezas del ingenio nacional. Biblioteca de Autores Españoles desde la Formación del Lenguaje hasta Nuestros Días. 176. Madrid: Atlas, 1964. 1-12.

FAULHABER, Charles B. "The Hawk in Melibea's Garden." Hispanic Review 45 (1977): 435-450.

FLORES, Juan de. Grisel y Mirabella. Ed. Barbara Matulka. The Novels of Juan de Flores and their European Diffusion: a Study in Comparative Literature. Geneva: Slatkine Reprints, 1974. 329-371.

FRADEJAS LEBRERO, José. "Cazar aves con lumbre (más antiguo aún).” 
Celestinesca 18.1 (1994): 75-77.

-... "Tres notas a la Celestina." Celestinesca 17.1 (1993): 47-56.

FRADEJAS RUEDA, José Manuel. "El 'boezuelo', el 'buey de caza' y el 'cabestrillo' 'privado.' “ Celestinesca 20.1-2 (1996): 155-70.

-.. Literatura cetrera de la edad media y el renacimiento español. Papers of the Medieval Hispanic Research Seminar 13. London: Department of Hispanic Studies, Queen Mary and Westfield College, 1998.

FRAKER, Charles F. "The Four Humors in Celestina." Corfis and Snow 129-154. GARCI-GÓMEZ, Miguel. "Ascendencia y trascendencia del neblí de Calisto." Revista de Literatura 49 (1987): 5-21.

GERLI, E. Michael. "Calisto's Hawk and the Images of a Medieval Tradition." Romania 104 (1983): 83-101.

--.. "A Propos the Pantomime Ox, Sexual Innuendo, and Fuddled Partridges: Yet More on Pármeno's Remark." Celestinesca 12.2 (1988): 55-59.

HOOK, David. "Andar a caça de perdizes con bueyes." Celestinesca 8.1 (1984): 47-48.

--.. “Pármeno’s 'Falso Boezuelo' Again." Celestinesca 9.1 (1985): 39-42.

JOSET, Jacques. "Una vez más 'el falso boezuelo.' “ Celestinesca 16.2 (1992): 77-80.

LACARRA, María Eugenia. "La evolución de la prostitución en la Castilla del siglo XV y la mancebía de Salamanca en tiempos de Fernando de Rojas." Corfis and Snow 33-78.

Libro de Alexandre: Texts of the Paris and Madrid Manuscripts. Ed. Raymond S. Willis. Elliott Monographs in the Romance Languages and Literatures. 32. Princeton: UP, 1934. (Repr. New York: Kraus, 1965).

LIDA DE MALKIEL, María Rosa. La originalidad artística de 'La Celestina'. Buenos Aires: EUDEBA, 1962.

LÓPEZ DE AYALA, Pero. Libro de la caşa de las aves: el MS 16.392 (British Library, Londres). Ed. John G. Cummins. Colección Támesis. Serie B. 30. London: Tamesis, 1986.

MABBE, James. The Spanish Bawd. Ed. Dorothy Sherman Severin. Celestina: With the Translation of James Mabbe (1631). Hispanic Classics. Mediaeval. Warminster: Aris \& Phillips, 1987.

MACPHERSON, Ian. "Secret Language in the Cancioneros: Some Courtly Codes." Bulletin of Hispanic Studies 62 (1985): 51-63.

MARTÍNEZ DE TOLEDO, Alfonso. Arcipreste de Talavera o Corbacho. Ed. J. González Muela. Clásicos Castalia. 24. Madrid: Castalia, 1970.

MANUEL, Juan. Libro de la caza. Ed. José Manuel Fradejas Rueda. May 2001. Universidad de Valladolid. 17 May 2001 < http://www.fyl.uva.es/ cetreria/ $>$.

--.. Libro del caballero et del escudero. Ed. Pascual de Gayangos. Escritores en prosa anteriores al siglo $X V$. Biblioteca de Autores Españoles desde la Formación del Lenguaje hasta Nuestros Días. 51. Madrid: Atlas, 1952. 234-257.

MCGRADY, Donald. "Calisto's Lost Falcon and its Implications for Dating 
Act I of the Comedia de Calisto y Melibea." Letters and Society in Fifteenth-Century Spain: Studies Presented to P. E. Russell on bis Eightieth Birthday. Ed. Alan Deyermond and Jeremy Lawrance. Llangrannog: Dolphin, 1993. 93-102.

-.-. "The Hunter Loses his Falcon: Notes on a Motif from Cligés to La Celestina and Lope de Vega." Romania 107 (1986 [1988]): 145-182.

PALAFOX, Eloísa. "Antes y después: la voz de Melibea en la transposición de la Comedia a la Tragicomedia." Cultural Contexts/Female Voices. Ed. Louise M. Haywood. Papers of the Medieval Hispanic Research Seminar. 27. London: Dept of Hispanic Studies, Queen Mary \& Westfield College, 2000. 51-62.

PERRINS, Christopher, Ed. New Generation Guide to the Birds of Britain and Europe. The Corrie Herring Hooks Series. 8. Austin: University of Texas Press, 1987.

PETERSON Roger, Guy MOUNTFORT, \& P.A.D. HOLLOM, eds. Guía de campo de las aves de España y de Europa. Barcelona: Omega, 1991.

Refranero Español: colección de ocho mil refranes populares, ordenados, concordados y explicados. Ed. José Bergua. Madrid: Clásicos Bergua, 1977.

ROGERS, Edith Randam. The Perilous Hunt: Symbols in Hispanic and European Balladry. Studies in Romance Languages. 22. Lexington: UP of Kentucky, 1980.

ROJAS, Fernando de. Celestina: With the Translation of James Mabbe (1631). Ed. Dorothy Sherman Severin. Hispanic Classics. Mediaeval. Warminster: Aris \& Phillips, 1987.

ROWLAND, Beryl. Animals with Human Faces: A Guide to Animal Symbol. ism. Knoxville: University of Tennessee Press, 1973.

---. Birds with Human Souls: A Guide to Bird Symbolism. Knoxville: University of Tennessee Press, 1978.

SENIFF, Dennis P. " 'El falso boezuelo con su blando cencerrar': or, The Pantomime Ox Revisited." Celestinesca 9.1 (1985): 43-45.

SEVERIN, Dorothy S. " 'El falso boezuelo', or the Partridge and the Pantomime Ox." Celestinesca 4.1 (1980): 31-33.

The Medieval Castilian Bestiary from Brunetto Latini's 'Tesoro': Study and Edition. Ed. Spurgeon Baldwin. Exeter Hispanic Texts. 31. Exeter: Univ., 1982.

WALSH, P. G. Andreas Capellanus on Love. Duckworth Classical, Medieval and Renaissance Editions. London: Duckworth, 1982.

WEINBERG, F. M. "Aspects of Symbolism in La Celestina." Modern Language Notes 86 (1971): 136-153.

WHINNOM, Keith. A Glossary of Spanish Bird-Names. Colección Támesis. Serie A. III. London: Tamesis, 1966.

.... "Dr Severin, the Partridge, and the Stalking Horse." Celestinesca 4.2 (1980): 23-25.

---. La poesía amatoria de la época de los Reyes Católicos. Durham Modern Languages Series. Hispanic Monographs. II. Durham: UP, 1981. 


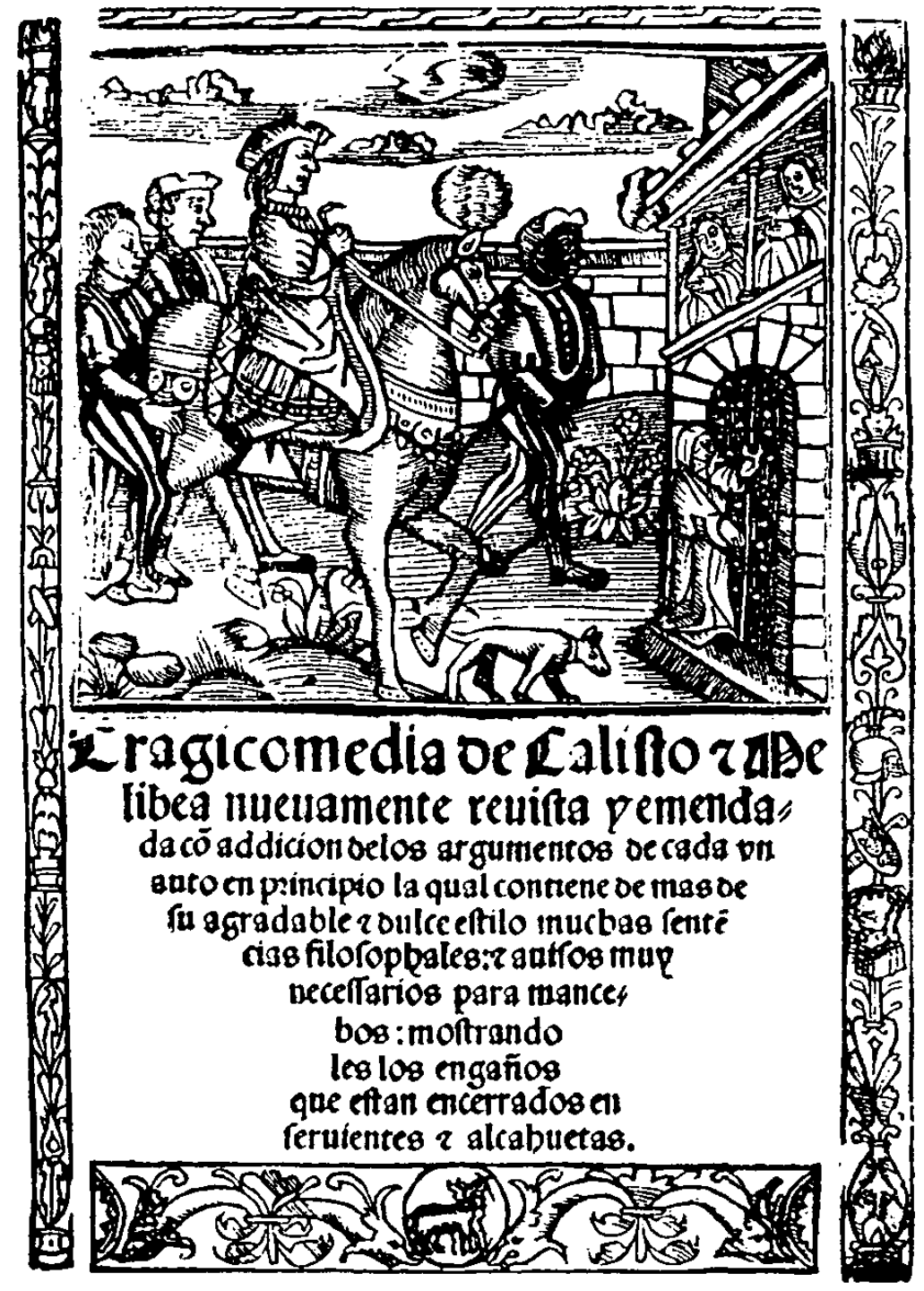

Valencia: Juan Viñao, 1529. Portada. 